\title{
Sacroiliac Joint Arthrodesis-MIS Technique with Titanium Implants: Report of the First 50 Patients and Outcomes
}

\author{
Leonard Rudolf*
}

Alice Peck Day Memorial Hospital, 129 Mascoma Street, Lebanon, NH 03766, USA

\begin{abstract}
This retrospective study of 50 consecutive patients treated by a single orthopedic spine surgeon in private practice was conducted to evaluate the safety and efficacy of minimally invasive sacroiliac joint fusion using a series of triangular, porous plasma spray coated titanium implants.

Medical charts were reviewed for perioperative metrics, complications, pain, quality of life and satisfaction with surgery. All patients were contacted at a 24 months post-op to assess SI joint pain, satisfaction with surgery and work status.

An early and sustained statistically significant improvement in pain function was identified at all post-operative time points (ANOVA, $\mathrm{p}<0.000$ ). A clinically significant improvement ( $>2$ point change from baseline) was observed in 7 out of 9 domains of daily living. The complication rate was low and more than $80 \%$ of patients would have the same surgery again.

MIS SI joint fusion appears to be a safe and effective procedure for the treatment of sacroiliac joint disruption or degenerative sacroiliitis.
\end{abstract}

Keywords: Arthrodesis, minimally invasive surgery, sacroiliac joint.

\section{INTRODUCTION}

Undertreated or unrelieved pain results in over $\$ 60$ billion dollars in lost income, medical expenses and lost productivity [1]. Up to $90 \%$ of adults experience back pain in their lifetime and back pain is the second most common reason for visits to primary care physicians [2]. Identifying the pain generator in patients reporting low back pain is a significant challenge. Pain from the sacroiliac (SI) joint can mimic discogenic or radicular low back pain and can present as low back, sacral, hip, pelvic, groin or gluteal pain, leading to the potential for inaccurate diagnosis and treatment [2-4]. Further, SI joint conditions have been cited as a possible cause of failed back surgery syndrome $[5,6]$. In a large retrospective study of 1,293 patients with low back pain published in 1987, Bernard and Kirkaldy-Willis found a $22.5 \%$ prevalence rate of SI joint pain in patients presenting with low back pain [7]. Other authors have described similar findings, reporting an SI joint pain prevalence rate of 15$30 \%$ in patients with low back pain $[4,8]$. Additionally, the SI joint seems to be affected by altered biomechanics after lumbar spinal fusion. Literature indicates $40 \%$ of postlumbar and lumbosacral fusion patients have SI joint pain and up to $75 \%$ of these patients develop radiographically detectable SI joint degeneration after 5 years [9-11].

Treatment options for patients with SI joint pain have focused on physical therapy and pain management including: medication optimization, physical therapy, SI joint injections, and radiofrequency ablation. For patients with long standing SI joint symptoms refractory to non-surgical

*Address correspondence to this author at the Alice Peck Day Memorial Hospital, 129 Mascoma Street, Lebanon, NH 03766, USA;

Tel: 603448 6344; Fax: 603448 3405; E-mail: leonardrudolf@gmail.com treatment, traditional open SI joint fusion surgery is an option. Open arthrodesis procedures reported in the literature require relatively large incisions, significant bone harvesting, and lengthy hospital stays; moreover, they require nonweight bearing for several months [12-15]. The recent trend in spine surgery has been to explore minimally invasive surgical (MIS) approaches to common pathology. Recent publications of percutaneous placement of ileosacral screws or threaded cages report relatively good clinical results $[16$, 17].

The purpose of this retrospective study is to evaluate the safety and effectiveness of an MIS SI joint fusion treatment using a series of triangular, porous plasma spray coated titanium implants placed across the SI joint. The objective of this surgery is to achieve arthrodesis through a permanent linkage across the joint, relying on bone ongrowth for permanent stabilization of the implant.

\section{METHODS}

We report treatment outcomes of the first 50 consecutive patients treated at a single, community based spine practice between October 2007 and July 2010. The medical charts of all 50 patients were reviewed for complications, pain, quality of life, satisfaction with surgery and return to work status up to 12-month follow up. At a minimum of 24 months postoperatively, all patients were contacted via telephone by the treating surgeon to assess SI joint pain, satisfaction with surgery and return to work status.

Mean age at the time of surgery was 54 years (range 2485 ) and most (68\%) patients were women (Table 1). Twenty two (44\%) patients had a history of previous lumbar spine fusion. Eight (16\%) patients had ongoing symptomatic lumbar spine pathology managed using conservative care. 
Table 1. Demographic Information

\begin{tabular}{|l|l|}
\hline Patients & 50 \\
\hline Age & $54($ range 24-85) \\
\hline Gender & $34 \mathrm{~F}(68 \%), 16 \mathrm{M}(32 \%)$ \\
\hline Prior lumbar fusion & $22(44 \%)$ \\
\hline $\begin{array}{l}\text { Presence of lumbar pathology } \\
\text { treated non-surgically }\end{array}$ & $8(16 \%)$ \\
\hline
\end{tabular}

Patients were diagnosed with either degenerative sacroiliitis or sacroiliac joint disruption using a combination of history, clinical exam, and positive diagnostic injection. All patients presented with chronic lower back pain refractory to prolonged conservative care. The most common chief complaint was posterior pain located close to the SI joint. A thorough physical and clinical exam was performed on all patients, emphasizing the lumbar spine, SI joint and hip axis. Provocative physical examination maneuvers were used to guide subsequent diagnostic activities. All patients with suspected SI joint pain underwent imaging with X-ray, $\mathrm{CT}$ and/or MRI to evaluate SI joint pathology and exclude lumbar spine and hip pathology. When clinical, physical and radiographic examinations were concordant, patients were sent for confirmatory image-guided injections of the SI joint. A $75 \%$ reduction in pain, as measured on a visual analog scale, immediately following injection of local anesthetic was used to confirm the SI joint as the pain generator [11].

MIS SI joint fusion using the iFuse Implant System (SIBONE, Inc., San Jose, CA) was performed in all cases by a single orthopedic spine surgeon. The surgical technique involves placing three porous plasma coated titanium implants across the SI joint.

\section{Implant Description}

The triangular shape of the titanium implant combined with an interference fit is designed to minimize rotation, micromotion, and avoid issues often seen with orthopedic screws, such as loosening and breakage [18]. The implant surface is prepared with a porous plasma spray coating, allowing for bone ongrowth across the joint, resulting in permanent fusion to the implants. The larger implant surface area and increased strength compared to a threaded screw is designed to maximize post-surgical weight bearing capacity. Biomechanical studies demonstrate the implant is 3 times stronger in shear and bending strength compared to an $8 \mathrm{~mm}$ cannulated screw (SI-BONE Inc. data on file). Implants are available in either a 4.0 or $7.0 \mathrm{~mm}$ inscribed diameter and in $5 \mathrm{~mm}$ incremental lengths from $30 \mathrm{~mm}$ to $70 \mathrm{~mm}$ to fit individual patient anatomy.

\section{Surgical Technique}

The procedure is performed under general anesthesia with the patient in the prone position. The lateral buttock and pelvis is prepped to allow a $3 \mathrm{~cm}$ skin incision. The gluteal fascia is penetrated bluntly and the muscle is split longitudinally to gain access to the outer table of the ilium. A Steinmann pin is placed through the ilium across the SI joint into the lateral portion of the sacrum (Denis zone I - Fig. 1) and lateral to the neural foramen [19]. The entire procedure is monitored using lateral, inlet, and outlet views on fluoroscopy. A depth gauge is used to determine implant length. Through the cannulated tissue protector, bone is prepared using a drill and triangular broach before the implant is inserted. The cephalad implant is routinely placed within the sacral ala (Fig. 2). A pin-guide system is used to facilitate placement of the subsequent implants. The second implant is generally located above or adjacent to the S1 foramen and the third between the S1 and S2 foramen (Denis zone I) (Figs. 3, 4). The incision is then irrigated and the tissue layers are closed with Vicryl and Monocryl.

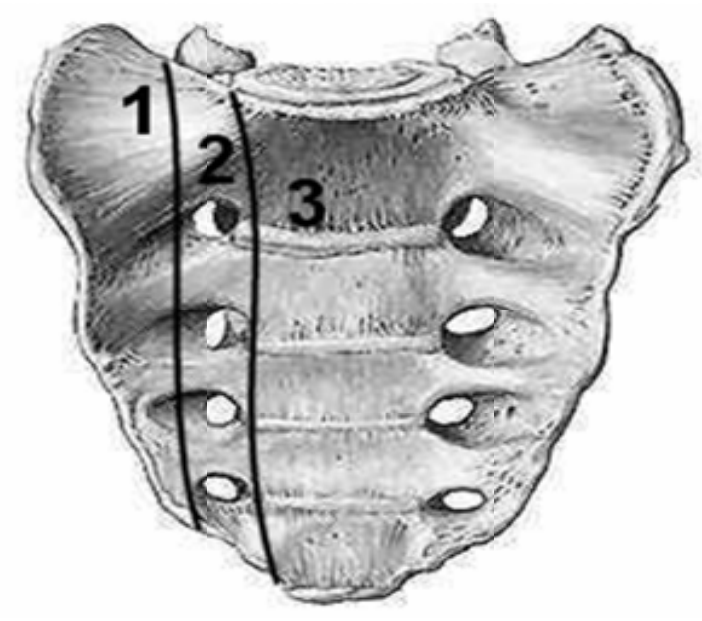

Fig. (1). Denis zones.

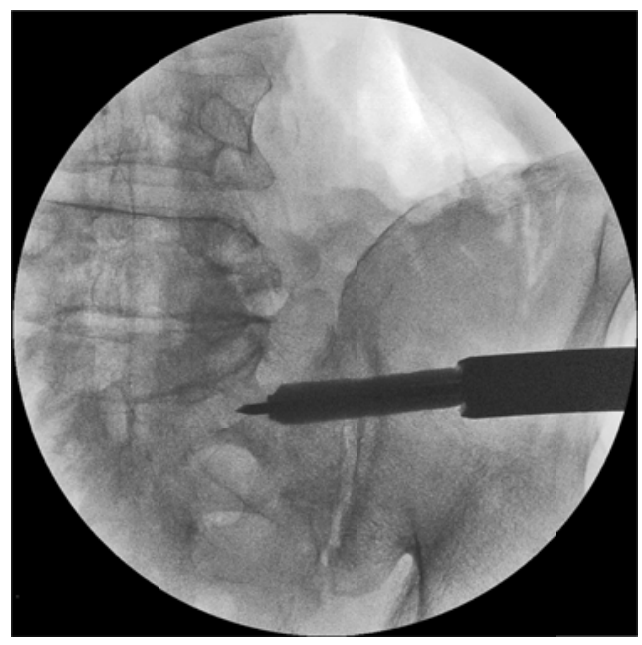

Fig. (2). Fluoroscopic image of the first implant placed over the Steinmann Pin.

In the reported cohort, 4 implants were placed unilaterally in one patient and bilaterally in another. Two short female patients received 2 implants each. All other patients received 3 implants. Four patients returned to have the contralateral side treated due to progressing symptoms and 1 patient underwent bilateral SI joint surgery on the same day.

Patients were required to use crutches for a period of time before resuming full activity. CT scans were performed immediately post-operatively and at the 6- or 12-month visit to assess implant status. An independent radiographic review of images acquired at the 6-month interval showed $95 \%$ of patients with boney ongrowth [20]. 


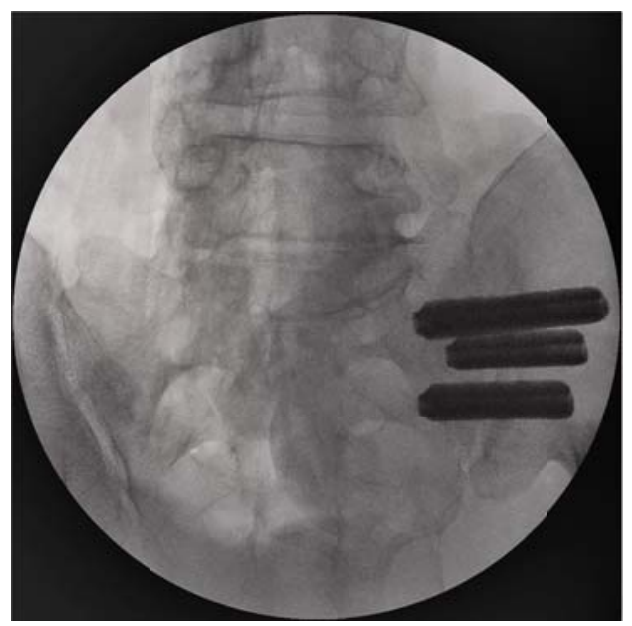

Fig. (3). AP fluoroscopic image of all 3 implants in place.

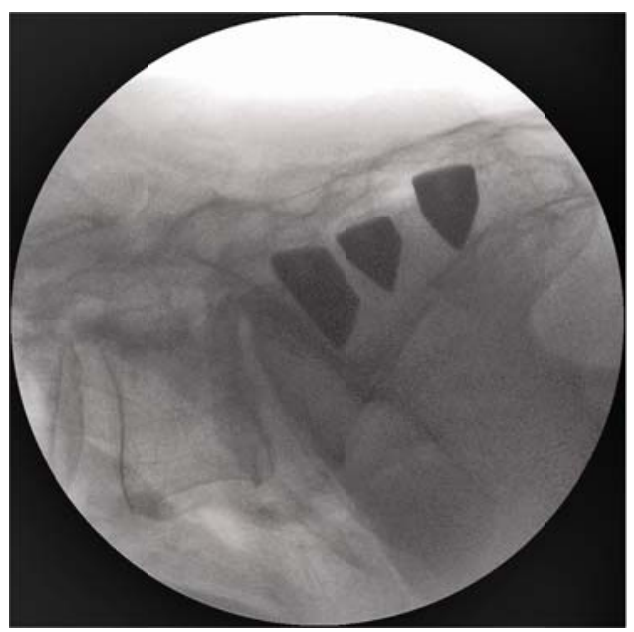

Fig. (4). Lateral fluoroscopic image of all 3 implants in place.

\section{Functional Outcome Assessment}

Pain and functional outcomes were assessed preoperatively and post-operatively at 3-, 6-, and 12-month follow-up visits using a novel patient outcomes questionnaire (Table 2). This outcomes instrument was created in order to reduce the burden of completing multiple lengthy questionnaires on patients and staff in this private practice setting. Questions were pulled from several validated instruments including SF-36 and Oswestry Disability Index. The survey asked patients to rate their pain and function in 9 domains as well as satisfaction with surgery and work status. A simple numerical rating scale (NRS) of 0-10 with 0 representing no pain or difficulty and 10 representing the worst pain imaginable or complete incapacitation was used for all domains.

In addition, all patients were contacted after a minimum of 24 months post-operatively via telephone to assess SI joint pain using a 0-10 NRS, work status, and satisfaction with surgery.

\section{RESULTS}

We report on the first consecutive 50 patients treated with minimally invasive SI joint fusion by a single surgeon. Four (8\%) patients underwent concomitant lumbar spine procedures at the time of SI joint fusion surgery. A total of 37 right-sided SI joints and 18 left sided joints were fused
(Table 3). Average ( \pm SD) operating time was $65 \pm 26$ minutes and blood loss was minimal $(<50 \mathrm{cc})$ in all cases.

Table 2. Quality of Life Questionnaire

\begin{tabular}{|ll|}
\hline 1. & $\begin{array}{l}\text { How much pain are you in at this time? } \\
\text { (Questions } 2,3,4) \text { How well are you able to perform: }\end{array}$ \\
\hline 2. & Light activities like walking a block or dressing yourself? \\
\hline 3. & Moderate activities like playing golf, walking half a mile, or dancing? \\
\hline 4. & Vigorous activities like running or moving furniture? \\
\hline 5. & How much is your sleep disturbed by pain at this time? \\
\hline 6. & How well are you able to lift items off the floor at this time? \\
\hline 7. & How would you assess your level of happiness at this time? \\
\hline 8. & How interested are you in socializing at this time? \\
\hline 9. & Because of pain, how much is your socializing limited at this time? \\
\hline
\end{tabular}

Table 3. Peri-Operative Characteristics

\begin{tabular}{|l|c|}
\hline Joints treated & 55 \\
\hline Right SI joint & 37 \\
\hline Left SI joint & 18 \\
\hline Bilateral surgery in one setting & 1 \\
\hline Staged bilateral fusion & 4 \\
\hline OR time (min) & $65 \pm 26$ \\
\hline Prior lumbar fusion & 22 \\
\hline Presence of lumbar spine pathology treated non-surgically & 8 \\
\hline Concomitant lumbar surgery & 4 \\
\hline
\end{tabular}

\section{Complications}

There were 10 peri-operative complications. Three patients who had subcuticular skin closure developed superficial cellulitis that resolved after a short course of oral antibiotics. No infections occurred after using Nylon skin sutures. One patient experienced a deep-soft tissue wound infection with gram-negative organism that resolved after 6 weeks of intravenous antibiotics. Two patients experienced a large buttock hematoma, with post-operative pain and difficulty sitting. Resolution was noted after 4-6 weeks, without residual symptoms.

Implant penetration into the sacral neural foramen was discovered on post-operative pelvic CT scan in 2 patients. Clinical exam revealed nerve root irritation and radicular pain without neurological deficit. Both patients were brought back to the OR and the misplaced implants were retracted to the edge of the neural foramen, resulting in complete resolution of symptoms.

In one patient with an unrecognized hemi-sacralized L5 transitional vertebrae, the first implant was inadvertently placed too cephalad, compressing the L5 nerve. This patient was brought back to the OR for a partial retraction of the implant and experienced a complete resolution of symptoms.

One patient had a non-displaced fracture located at the inferior edge of the ilium adjacent to the sciatic notch at the 
edge of the lowest implant. The fracture healed without intervention. CT scans performed at 12 months on all 10 patients revealed evidence of bone ongrowth with no suggestion of implant loosening.

One late complication occurred. Three years after surgery, a patient presented with persistent and gradually increasing SI joint pain. CT of the pelvis showed findings suggestive of motion surrounding the sacral end of the 2 most caudal implants, which were noted to be positioned posteriorly rather than central and anterior in the sacroiliac joint. A CT-guided injection confirmed the SI joint as the pain generator. Two additional $7.0 \mathrm{~mm}$ implants were placed anteriorly to the loosened implants, resulting in complete symptom resolution.

\section{Clinical Outcomes}

Of 50 patients treated, quality of life questionnaires were available for 49 patients pre-operatively, 41 patients at 3months, 40 at 6-months and 27 at 12-months. Results for the 4 patients who underwent concomitant lumbar spine procedures were excluded from analysis. A repeated analysis of variance (ANOVA, PROC MIXED) was performed using SAS version 9.0 (Cary, NC) to evaluate change in pain and function across post-operative time points. Clinical significance was defined as an improvement of 2 points from baseline [21].

Patients showed an early and sustained clinically and statistically significant improvement in 7 out of 9 domains at all time points (Table 4). The most dramatic improvement was observed in pain with scores decreasing by 3.92, 4.36, and 4.29 points at the 3-, 6-, and 12-month intervals respectively $(p<0.0001)$. The percentage of individual patients who experienced a clinically significant benefit was $78 \%, 85 \%$, and $71 \%$ at the respective intervals. The ability to perform activities, regardless of perceived difficulty (light, moderate or vigorous) showed early and continued improvement; though there were no statistically significant differences across postoperative follow up time points $(\mathrm{p}<$. 0001). Sleep disturbance caused by pain showed an early and durable improvement, decreasing by an average of 3 points at all postoperative visits $(\mathrm{p}<0.0001)$. Compared to baseline, there was a statistically significant improvement in overall happiness at all time points $(\mathrm{p}=0.002)$. The reported effect of pain on patient's social life improved at all three time points $(p<0.001)$. Scores for lifting ability and general social interest showed little to no improvement from baseline at all time points. Patient-reported satisfaction with treatment was high: $91 \%$ of patients at 3 -months, and $82 \%$ at $6-$ and $12-$ months would have the same surgery again.

We attempted to contact all 50 patients at a minimum 24month follow up via telephone to assess SI joint pain, satisfaction with surgery and return to work status. Fortyfive patients were available for follow up: three patients were lost to follow up and two patients died, both from unrelated conditions. Mean follow up was 40-months (range 24-56 months). The mean $( \pm \mathrm{SD})$ pain score was $2.0(2.8)$ with $82 \%$ of patients reaching MCID ( $>2$ point change). Compared to baseline, the mean improvement was 5.59 (3.5 SD) points, representing a clinically and statistically significant $(\mathrm{p}<$. 0001) improvement. Although pain scores were lowest at this time point, a repeated analysis of variance analysis revealed no statistically significant difference across various postoperative time points $(\mathrm{p}=0.10)$. All patients who reached MCID, and none who did not, reported satisfaction with surgery $(82 \%)$, indicating that satisfaction was correlated with symptom improvement. At baseline, $30 \%$ of patients were retired/unemployed, 36\% were employed. At follow up, these patients had no change in status. Thirteen patients previously disabled were able to return to work. Three patients retired and work status did not change for 2 patients not working due to disability at baseline (ages 83 and 62).

\section{DISCUSSION}

SI joint symptoms can present as pain in the SI joint, low back, hip, groin, or buttock. As a result, a careful and thorough clinical and physical exam must be performed to correctly identify the pain generator. Positive provocative maneuvers combined with $75 \%$ pain relief after image guided SI joint injection(s) is a reliable method for diagnosing the SI joint as the pain generator [22, 23].

SI joint arthrodesis has been previously described as a treatment option for pain refractory to conservative care. As with many spinal conditions, there is no set standard protocol for conservative care in this population. Various methods are described in the literature and diagnostic standards typically

Table 4. Results: Quality of Life Outcomes

\begin{tabular}{|c|c|c|c|c|c|c|c|c|}
\hline & $\begin{array}{c}\text { Baseline } \\
\text { Mean }\end{array}$ & \multicolumn{2}{|c|}{3 Month $(n=44)$} & \multicolumn{2}{|c|}{6 Month $(n=41)$} & \multicolumn{2}{|c|}{12 Month (n=27) } & $\frac{\text { ANOVA }}{p}$ \\
\hline Light activities & 5.6 & -2.09 & 2.90 & -2.44 & 2.72 & -2.61 & 3.01 & $<.0001$ \\
\hline Moderate activities & 7.8 & -1.88 & 3.58 & -3.5 & 3.61 & -2.59 & 4.01 & $<.0001$ \\
\hline Sleep & 6.8 & -3.17 & 3.16 & -3.26 & 3.07 & -3.04 & 3.77 & $<0.0001$ \\
\hline Lifting & 5.9 & -0.81 & 3.51 & 0.05 & 3.08 & -0.09 & 4.26 & 0.326 \\
\hline Overall happiness & 6.3 & -1.91 & 3.88 & -2.49 & 3.52 & -2.39 & 3.37 & 0.0022 \\
\hline Social Interest & 5.2 & -0.32 & 3.96 & 0.59 & 4.22 & 0.36 & 4.16 & 0.4968 \\
\hline
\end{tabular}


include positive provocative maneuvers and/or pain relief after SI joint block [6, 12-16, 24-34]. Buchowski et al. reported significant improvements in pain and function as measured by SF-36 on 20 patients who underwent SI joint arthrodesis using a posterior modified Smith-Peterson technique [12]. The Smith Peterson technique involves excision of a $2.5 \times 3.5 \mathrm{~cm}$ iliac bone graft that is then secured within the SI joint using $6.5 \mathrm{~mm}$ AO bone screws. Buchowski et al. modified this technique to remove the bone window directly over the SI joint, exposing the articular surface of the joint. The joint surface was curetted prior to graft reinsertion and fixation with plates and screws. Reported complications included a $15 \%$ nonunion rate that required revision using an anterior approach and two associated deep wound infections. Although open surgery may result in positive pain and function improvements, the procedure is invasive and comes with a high revision rate.

Arthrodesis using a percutaneous approach with screws or threaded cages has been described with positive results. Al-Khayer et al. reported on 9 patients using a single hollow modular anchorage (HMA) screw packed with bone graft [16]. All patients experienced a clinically significant improvement in VAS pain scores and all but 1 patient improved in function. One patient suffered a deep wound infection. Khurana at al. also report on an HMA with demineralized bone matrix in a cohort of 15 patients with relatively good outcomes [32]. Wise and Dall reported good clinical results after fusing 13 patients with an $11 \times 25 \mathrm{~mm}$ threaded cage packed with rhBMP-2 [17]. The cage was inserted posteriorly within the joint rather than across the joint as reported in previous studies. Due to the off-label nature and elevated cost associated with rhBMP-2, autologous iliac crest harvest was suggested. However, studies suggest that this can lead to further degeneration of the SI joint [12]. The various MIS methods described represent an improvement to the open surgical technique but leave room for improvement in technique and patient outcomes.

It is well known that minimally invasive methods for other surgical procedures have reduced peri-operative morbidity. Advantages of this reported MIS SI joint fusion implant technique include a small incision, minimal blood loss, bone and ligament preservation, and a relatively short period of immobilization.

The learning curve for this minimally invasive procedure was relatively low. Incision location was slightly modified based on two incidents of postoperative buttock hematoma. The etiology of these hematomas was postulated to be an injury to a branch of the superior gluteal artery due to an inferior/anterior approach on the buttock. The incision location was modified to allow for a more posterior penetration of the gluteal muscle without further incident of hematoma. Early on in our experience, a post-op pelvic CT scan was performed on all patients to assess implant placement. To avoid possible nerve root irritation, the implants should be seated central and anterior to the SI joint with particular attention paid to the depth of implant placement.
In our cohort of patients undergoing MIS SI joint fusion using the iFuse implant, clinical outcomes were favorable: $82 \%$ at 40 months experienced a clinically significant benefit. Mean improvements in quality of life measures were statistically and clinically significant at all time points. A comparison of previously reported literature reveals similar blood loss compared to other MIS techniques and as expected, lower rates of blood loss compared to open surgical procedures (Table 5). Patients in the current cohort reported a greater improvement in pain relief compared to historic controls at the 40-month follow up period. Pain scores improved by an average of 5.9 points $(n=45)$ compared to 3.5 points $(n=9)$ reported by Al-Khayer, and 4.9 points $(n=13)$ reported by $W$ ise at a similar time point $[16$, 17]. The complication rate in this cohort was $20 \%$, which is average compared to the literature. It should be noted that half of these adverse events were minor requiring little if any intervention, including mild hematoma at incision site and superficial cellulitis. In addition, the revision rate of $8 \%$ after three years is comparatively low, particularly when taken in the context of the learning curve of a novel procedure.

To our knowledge, this is the largest known case series on SI joint fusion in the published literature to date. Limitations of this study include small sample size, single surgeon experience, a non-standard outcomes measure and absence of a comparator group. In our review of available literature on various SI joint fusion techniques, less than half of the case series reports used any standard validated outcomes tool. The small number of patients available at the 12 -month interval compared to 6 months was due in part to our discharge procedure. As a private practice office, patients are routinely discharged after 6 months if there are no ongoing findings requiring investigation. For this study, patients were contacted and reported outcomes at 40-months.

This study also has strengths. All patients were from a single center, which ensured a consistent diagnostic and therapeutic approach. Our results validate the SI joint as a potential pain generator in patients with low back pain and previous lumbar fusion. Clinicians are encouraged to investigate the SI joint as a possible source of pain in order to avoid unnecessary repeat lumbar spine surgery. Prospective studies are currently underway to further evaluate this technology.

\section{CONCLUSION}

When conservative measures fail, minimally invasive SI joint fusion using a series of triangular porous plasma coated titanium implants is a safe and effective treatment option in carefully selected patients.

\section{CONFLICT OF INTEREST}

No funds were received in support of this research. The author hold stock in and is a consultant for SI-BONE, Inc., the manufacturer of the implant used in this study.

\section{ACKNOWLEDGEMENTS}

The author wishes to acknowledge Robyn Capobianco for data analysis and editorial review. 
Table 5. Comparative Studies. All Studies are Consecutive Case Series

\begin{tabular}{|c|c|c|c|c|c|c|}
\hline Author, Year & $\mathbf{N}$ & Demographics & $\begin{array}{l}\text { Diagnostic } \\
\text { Standard }\end{array}$ & $\begin{array}{c}\text { Surgical Procedure/Post-Op } \\
\text { Care }\end{array}$ & Results & Complications \\
\hline $\begin{array}{l}\text { Kibsgard, } 2012 \\
{[33]}\end{array}$ & 50,28 & $\begin{array}{l}\text { Fusion (50 pts) } \\
\text { Age: } 58 \\
\text { Gender: } 47 \mathrm{~F} / 3 \mathrm{M} \\
\text { Follow-up: } 23 \mathrm{yrs} \\
\text { Unilateral } 21 / \text { Bilateral } \\
25 \\
\text { Dx: Post-partum (30), } \\
\text { Trauma (8), Idiopathic } \\
\text { (12) } \\
\text { Non-Surgery (28 pts) } \\
\text { Age: } 52 \\
\text { Gender: } 28 \mathrm{~F} \\
\text { Follow-up: } 17 \mathrm{yrs}\end{array}$ & $\begin{array}{l}\text { PSIS tenderness, } \\
\text { positive straight leg } \\
\text { raise, positive } \\
\text { provocative } \\
\text { maneuvers }\end{array}$ & $\begin{array}{l}\text { Trans-iliac fusion or } \\
\text { intra/extra-articular fusion } \\
\text { between the ilium and the } \\
\text { sacrum using cortical iliac } \\
\text { window and iliac crest } \\
\text { autograft. } \\
\text { Post-op care: In most cases } \\
\text { the patients were confined to } \\
6 \text { weeks of bed rest. }\end{array}$ & $\begin{array}{l}\text { Surgical patients after } 1 \\
\text { year: } 24(48 \%) \text { patients } \\
\text { were good, } 12(24 \%) \\
\text { were fair, and } 14(28 \%) \\
\text { were poor. } \\
\text { No significant difference } \\
\text { in ODI, VAS, or SF-36 } \\
\text { between surgery and } \\
\text { non-surgery patients after } \\
\text { long-term follow-up. }\end{array}$ & $\begin{array}{l}\text { Reoperation: } 7 \\
\text { Nonunion: } 8 \\
\text { Jaundice: } 1 \\
\text { Pulmonary embolism: } 1 \\
\text { Pin tract infection: } 1 \\
\text { Complication rate: } 20 \% \\
\text { Revision rate: } 14 \%\end{array}$ \\
\hline $\begin{array}{l}\text { Khurana, } 2009 \\
{[31]}\end{array}$ & 15 & $\begin{array}{l}\text { Age: } 48.7 \text { years } \\
\text { Gender 11F/4M } \\
\text { Follow-up: } 17 \text { months } \\
\text { Unilateral 11/Bilateral } 4 \\
\text { Previous lumbar } \\
\text { surgery: } 6 \\
\text { Dx: Osteoarthritis (7), SI } \\
\text { joint dysfunction(4), SI } \\
\text { joint instability (3), } \\
\text { Inflammatory Arthritis } \\
\text { (1) }\end{array}$ & $\begin{array}{l}\text { Tenderness over the } \\
\text { posterior SI joint, } \\
\text { positive provocative } \\
\text { maneuvers, pain } \\
\text { relief with SI joint } \\
\text { block }\end{array}$ & $\begin{array}{l}10 \text { mm Hollow Modular } \\
\text { Anchorage Screw packed } \\
\text { with demineralized bone } \\
\text { matrix across the SI joint. } \\
\text { Post-op care: Partial weight } \\
\text { bearing for six weeks and full } \\
\text { weight bearing by } 12 \text { weeks. }\end{array}$ & $\begin{array}{l}\text { Blood loss: }<50 \mathrm{ml} \\
\text { LOS } 2.7 \text { days } \\
\text { SF-36 increased: PF } 37 \\
\text { to } 80, \text { GH } 53 \text { to } 86 \\
\text { Majeed's: } 37 \text { to } 79 \\
\text { Good/Excellent: } 13 / 15 \\
\text { Fusion in all patients }\end{array}$ & None reported \\
\hline $\begin{array}{l}\text { Al-Khayer } \\
2008[16]\end{array}$ & 9 & $\begin{array}{l}\text { Age: } 42 \text { years } \\
\text { Gender: } 9 \mathrm{~F} \\
\text { Follow-up: } 40 \text { mo } \\
\text { Unilateral 6/Bilateral } 3 \\
\text { Symptom Duration: } 30 \\
\text { mo } \\
\text { Prior treatments: Failed } \\
\text { conservative treatment } \\
\text { Dx: Chronic SI joint } \\
\text { pain }\end{array}$ & $\begin{array}{l}\text { Tenderness over the } \\
\text { sacral sulcus, } \\
\text { positive provocative } \\
\text { maneuvers, } \\
\text { X-rays to exclude } \\
\text { other pain sources, } \\
\text { relief from SI joint } \\
\text { block }\end{array}$ & $\begin{array}{l}10 \mathrm{~mm} \text { Hollow Modular } \\
\text { Anchorage Screw packed } \\
\text { with demineralized bone } \\
\text { matrix across the SI joint. } \\
\text { Post-op care: early } \\
\text { mobilization w/in pain limits }\end{array}$ & $\begin{array}{l}\text { Blood loss: }<50 \mathrm{ml} \\
\text { No screw loosening, } \\
\text { nonunion, or failure } \\
\text { LOS: } 6.9 \text { days } \\
\text { Return to work: } 4 / 9 \\
\text { ODI decreased: } 59 \text { to } 45 \\
\text { VAS decreased: } 8.1 \text { to } \\
4.6 \\
\text { Satisfaction: } 6.8 \text { (out of } \\
10 \text { ) }\end{array}$ & $\begin{array}{l}1 \text { deep wound infection } \\
\text { Complication rate: } 11 \%\end{array}$ \\
\hline Wise, 2008 [17] & 13 & $\begin{array}{l}\text { Age: } 53 \text { years } \\
\text { Gender: } 12 \mathrm{~F} / 1 \mathrm{M} \\
\text { Follow-up: } 29.5 \text { mo } \\
\text { Unilateral } 7 / \text { Bilateral } 6 \\
\text { Previous lumbosacral } \\
\text { surgery: } 8 / 13 \\
\text { Prior treatments: Failed } \\
>6 \text { mo of conservative } \\
\text { therapy }\end{array}$ & $\begin{array}{l}\text { Relief with SI joint } \\
\text { block }\end{array}$ & $\begin{array}{l}\text { 9mm hole drilled through the } \\
\text { longitudinal aspect of the SI } \\
\text { joint. } 2 \text { cages packed with } \\
\text { BMP placed across the } \\
\text { anterior portion of the SI joint. } \\
\text { Post-op care: limited waist } \\
\text { bending, and a sacral belt for } \\
6 \text { mo; full activity at } 6 \text { mo }\end{array}$ & $\begin{array}{l}\text { Blood loss: }<100 \mathrm{ml} \\
\text { Length of stay: } 1.7 \text { days } \\
\text { Fusion rate: } 89 \% \\
\text { Low back VAS } \\
\text { improved } 4.9 \text { pts } \\
\text { Leg VAS improved } 2.4 \\
\text { pts }\end{array}$ & $\begin{array}{l}\text { Reoperation (nonunion): } 1 \\
\text { Complication and Revision } \\
\text { rate: } 8 \%\end{array}$ \\
\hline $\begin{array}{l}\text { Buchowski, } \\
2005[12]\end{array}$ & 20 & $\begin{array}{l}\text { Age: } 45 \text { years } \\
\text { Gender: } 17 \mathrm{~F} / 3 \mathrm{M} \\
\text { Follow-up: } 5.8 \text { yrs } \\
\text { Prior treatments: All } \\
\text { failed nonoperative } \\
\text { treatment } \\
\text { Previous spine surgery: } \\
15 / 20 \\
\text { Symptom Duration: } 2.6 \\
\text { yrs } \\
\text { Dx: SI joint dysfunction } \\
\text { (13), Osteoarthritis (5), } \\
\text { Spondyloarthropathy } \\
\text { (1), SI joint instability } \\
\text { (1) }\end{array}$ & $\begin{array}{l}\text { Sacral sulcus } \\
\text { palpation, } \\
\text { positive provocative } \\
\text { maneuvers, } \\
\text { Pain relief with } \\
\text { intraarticular SI joint } \\
\text { injections }\end{array}$ & $\begin{array}{l}\text { Modified Smith-Petersen } \\
\text { Incision over posterior } 2 / 3 \text { of } \\
\text { iliac crests. Graft stabilized w/ } \\
\text { plate and screws. } \\
\text { Post-op care: Non-weight } \\
\text { bearing for at least } 3 \text { months. }\end{array}$ & $\begin{array}{l}\text { Blood loss: } 290 \mathrm{~mL} \\
\text { Solid fusion: } 17 \\
\text { LOS: } 5.2 \text { days } \\
\text { Return to work: } 8 / 20 \\
\text { SF-36 improved (except } \\
\text { GH \& MH) } \\
\text { AAOS MODEMS sig. } \\
\text { improved (except } \\
\text { Comorbidity) } \\
\text { 60\% would have surgery } \\
\text { again }\end{array}$ & $\begin{array}{l}\text { Pseudoarthrosis: } 3 \\
\text { Deep wound infection: } 2 \\
\text { Painful hardware: } 1 \\
\text { Revision surgery (anterior): } 3 \\
\text { Complication rate: } 30 \% \\
\text { Revision rate: } 15 \%\end{array}$ \\
\hline $\begin{array}{l}\text { Giannikas, } \\
2004 \text { [13] }\end{array}$ & 5 & $\begin{array}{l}\text { Age: } 22 \text { to } 44 \text { years } \\
\text { Gender: } 3 \mathrm{~F} / 2 \mathrm{M} \\
\text { Follow-up: } 29 \text { mo } \\
\text { Symptom Duration: } 10 \\
\text { to } 40 \text { mo } \\
\text { Dx: Idiopathic (1), } \\
\text { Previous trauma (4) }\end{array}$ & $\begin{array}{l}\text { SI joint tenderness, } \\
\text { positive provocative } \\
\text { maneuvers, bone } \\
\text { scan, relief with SI } \\
\text { joint block }\end{array}$ & $\begin{array}{l}\text { Two bone plugs harvested } \\
\text { from the iliac crest and placed } \\
\text { through the superior and } \\
\text { inferior aspects of the SI Joint. } \\
\text { Post-op care: Non-weight } \\
\text { bearing for at least } 3 \text { months. }\end{array}$ & $\begin{array}{l}\text { Complete pain relief: } 4 / 5 \\
\text { Partial pain relief: } 1 / 5\end{array}$ & None reported \\
\hline
\end{tabular}




\begin{tabular}{|c|c|c|c|c|c|c|}
\hline Author, Year & $\mathbf{N}$ & Demographics & $\begin{array}{l}\text { Diagnostic } \\
\text { Standard }\end{array}$ & $\begin{array}{c}\text { Surgical Procedure/Post-Op } \\
\text { Care }\end{array}$ & Results & Complications \\
\hline $\begin{array}{l}\text { Moore, } 1997 \\
{[15]}\end{array}$ & 77 & $\begin{array}{l}\text { Gender: } 48 \mathrm{~F} / 29 \mathrm{M} \\
\text { Unilateral } 74 / \text { Bilateral } 3 \\
\text { Prior treatments: Failed } \\
6 \text { months of rehab } \\
\text { programs } \\
\text { Symptom duration: } 6 \text { to } \\
84 \text { mo } \\
\text { Follow-up: } 1 \text { to } 5 \text { years } \\
\text { Dx: Chronic painful } \\
\text { dysfunction }\end{array}$ & $\begin{array}{l}\text { Relief with SI joint } \\
\text { block }\end{array}$ & $\begin{array}{l}\text { Modified Smith-Petersen } \\
\text { technique with } 15 \mathrm{~cm} \text { incision } \\
\text { to reveal the ilium and } \\
\text { sacrum. Bone harvested from } \\
\text { the ilium and placed in the SI } \\
\text { joint after removing the } \\
\text { cartilage. } 2-3 \text { cannulated } \\
\text { screws to lock graft in place. } \\
\text { Post-op care: Non-weight } \\
\text { bearing for } 8 \text { weeks. }\end{array}$ & $62 / 77$ successful $(80.5 \%)$ & $\begin{array}{l}\text { Superficial wound infection: } \\
1 \\
\text { Post-op radicular pain: } 1 \\
\text { Sciatic notch fracture: } 1 \\
\text { Pseudoarthrosis: } 7 \\
\text { Complication rate: } 13 \%\end{array}$ \\
\hline $\begin{array}{l}\text { Keating, } 1995 \\
{[26]}\end{array}$ & 26 & $\begin{array}{l}\text { Age: } 38.3 \text { years } \\
\text { Follow-up: } 16 \text { weeks } \\
\text { Prior treatments: Failed } \\
6 \text { weeks of aggressive } \\
\text { rehab } \\
\text { Symptom duration: } 38.3 \\
\text { mo } \\
\text { Dx: Chronic LBP }\end{array}$ & $\begin{array}{l}\text { Relief with SI joint } \\
\text { block }\end{array}$ & $\begin{array}{l}\text { Inferior SI joint debrided, } \\
\text { decorticated, and packed with } \\
\text { bone graft. Secured with } 2 \\
\text { lateral compression screws. } \\
\text { Post-op care: } 16 \text { week } \\
\text { rehabilitation program. }\end{array}$ & $\begin{array}{l}\text { Pain decreased: } 6.1 \text { to } 2.9 \\
\text { Work Status increased: } \\
2.3 \text { to } 3.3 \\
5 \text { patients returned to } \\
\text { work after } 16 \text { mo of } \\
\text { unemployment }\end{array}$ & None reported \\
\hline $\begin{array}{l}\text { Waisbrod, } 1987 \\
{[34]}\end{array}$ & 21 & $\begin{array}{l}\text { Age: } 42 \\
\text { Gender: } 18 \mathrm{~F} / 3 \mathrm{M} \\
\text { Follow-up: } 30 \text { mo } \\
\text { Previous spine surgery: } \\
7 / 21 \\
\text { Symptom duration: > } 2 \\
\text { years } \\
\text { Dx: SI joint pain }\end{array}$ & $\begin{array}{l}\text { Tenderness over the } \\
\text { SI joint, positive } \\
\text { provocative } \\
\text { maneuvers, pain } \\
\text { provocation w/ } \\
\text { NaCL injection, } \\
\text { relief w/ SI joint } \\
\text { block }\end{array}$ & $\begin{array}{l}\text { SI joint excised and packed w/ } \\
\text { iliac crest bone graft and } \\
\text { ceramic blocks. } \\
\text { Post-op care: Spica cast for } 8 \\
\text { weeks. }\end{array}$ & $11 / 21$ Satisfactory results & $\begin{array}{l}\text { Pseudoarthrosis: } 2 \\
\text { Infection: } 1 \\
\text { Complication rate: } 14 \%\end{array}$ \\
\hline
\end{tabular}

\section{REFERENCES}

[1] Murray W. Sacroiliac joint dysfunction: a case study. Orthop Nurs 2011; 30(2): 126-31.

[2] Weksler N, Velan GJ, Semionov M, et al. The role of sacroiliac joint dysfunction in the genesis of low back pain: the obvious is not always right. Arch Orthop Trauma Surg 2007; 127(10): 885-8.

[3] Foley BS, Buschbacher RM. Sacroiliac joint pain: anatomy, biomechanics, diagnosis, and treatment. Am J Phys Med Rehabil 2006; 85(12): 997-1006.

[4] Schwarzer AC, Aprill CN, Bogduk N. The sacroiliac joint in chronic low back pain. Spine 1995; 20(1): 31-7.

[5] Waguespack A, Schofferman J, Slosar P, Reynolds J. Etiology of long-term failures of lumbar spine surgery. Pain Med 2002; 3(1): 18-22.

[6] Slipman $\mathrm{CW}$, Shin $\mathrm{CH}$, Patel RK, et al. Etiologies of failed back surgery syndrome. Pain Med 2002; 3(3): 200-14; discussion 214-7.

[7] Bernard TN, Kirkaldy-Willis WH. Recognizing specific characteristics of nonspecific low back pain. Clin Orthop Relat Res 1987; (217): 266-80.

[8] Sembrano JN, Polly DW. How often is low back pain not coming from the back? Spine 2009; 34(1): E27-32.

[9] Ha K-Y, Lee J-S, Kim K-W. Degeneration of sacroiliac joint after instrumented lumbar or lumbosacral fusion: a prospective cohort study over five-year follow-up. Spine 2008; 33(11): 1192-8.

[10] DePalma MJ, Ketchum JM, Saullo TR. Etiology of chronic low back pain in patients having undergone lumbar fusion. Pain Med 2011; 12(5): 732-9.

[11] Maigne JY, Planchon CA. Sacroiliac joint pain after lumbar fusion. A study with anesthetic blocks. Eur Spine J 2005; 14(7): 654-8.

[12] Buchowski JM, Kebaish KM, Sinkov V, Cohen DB, Sieber AN, Kostuik JP. Functional and radiographic outcome of sacroiliac arthrodesis for the disorders of the sacroiliac joint. Spine J 2005; 5(5): 520-8; discussion 529 .

[13] Giannikas KA, Khan AM, Karski MT, Maxwell HA. Sacroiliac joint fusion for chronic pain: a simple technique avoiding the use of metalwork. Eur Spine J 2004; 13(3): 253-6.

[14] Smith-Petersen MN. Arthrodesis of the sacroiliac joint. A new method of approach. J Bone Joint Surg Am 1921; 3(8): 400-5.

[15] Moore MR. Surgical treatment of chronic painful sacroiliac joint dysfunction. Movement, stability, and low back pain : the essential role of the pelvis. New York: Churchill Livingstone; 1997. pp. 56372.
Al-Khayer A, Hegarty J, Hahn D, Grevitt MP. Percutaneous sacroiliac joint arthrodesis: a novel technique. J Spinal Disord Tech 2008; 21(5): 359-63.

[17] Wise CL, Dall BE. Minimally invasive sacroiliac arthrodesis: outcomes of a new technique. J Spinal Disord Tech 2008; 21(8): 579-84.

[18] Routt MLC, Simonian PT, Inaba J. Iliosacral screw complications. Operat Tech Orthop 1997; 7(7): 206-20.

[19] Denis F, Davis S, Comfort T. Sacral fractures: an important problem. Retrospective analysis of 236 cases. Clin Orthop Relat Res 1988; 227: 67-81.

[20] Kim J, Rudolf LM, Glaser J. Radiographic and surgical outcomes of percutaneous SI joint fixation with porous plasma coated titanium implant: an independent review. 2012: Proceedings of the International Society for the Study of the Lumbar Spine. 28 May 1June 2012; Amsterdam, Netherlands.

[21] Copay AG, Glassman SD, Subach BR, Berven S, Schuler TC, Carreon LY. Minimum clinically important difference in lumbar spine surgery patients: a choice of methods using the Oswestry Disability Index, Medical Outcomes Study questionnaire Short Form 36, and pain scales. Spine J 2008; 8(6): 968-74.

[22] Szadek KM, van der Wurff P, van Tulder MW, Zuurmond WW, Perez RSGM. Diagnostic validity of criteria for sacroiliac joint pain: a systematic review. J Pain 2009; 10(4): 354-68.

[23] Liliang P-C, Lu K, Liang C-L, Tsai Y-D, Wang K-W, Chen H-J. Sacroiliac joint pain after lumbar and lumbosacral fusion: findings using dual sacroiliac joint blocks. Pain Med 2011; 12(4): 565-70.

[24] Campbell WC. An operation for extra-articular fusion of the sacroiliac joint. Surg Gynecol Obstet 1927; 45: 218-9.

[25] Gaenslen FJ. Sacro-iliac arthrodesis: indications, author's technic and end-results. JAMA 1927; 89(24): 2031-5.

[26] Keating J, Sims V, Avillar M. Sacroiliac joint fusion in a chronic low back pain polpulation. The integrated function of the lumbar spine and sacroiliac joint. Rotterdam: ECO 1995; pp. 361-5.

[27] Belanger TA, Dall BE. Sacroiliac arthrodesis using a posterior midline fascial splitting approach and pedicle screw instrumentation: a new technique. J Spinal Disord 2001; 14(2): $118-24$.

[28] Rand JA. Anterior sacro-iliac arthrodesis for post-traumatic sacroiliac arthritis. A case report. J Bone Joint Surg Am 1985; 67(1): $157-9$. 
[29] Güner G, Gürer S, Elmali N, Ertem K. Anterior sacroiliac fusion: a new video-assisted endoscopic technique. Surg Laparosc Endosc 1998; 8(3): 233-6.

[30] Smith HE, Yuan PS, Sasso R, Papadopolous S, Vaccaro AR. An evaluation of image-guided technologies in the placement of percutaneous iliosacral screws. Spine 2006; 31(2): 234-8.

[31] Khurana A, Guha AR, Mohanty K, Ahuja S. Percutaneous fusion of the sacroiliac joint with hollow modular anchorage screws: clinical and radiological outcome. J Bone Joint Surg Br 2009; 91(5): 627-31
[32] Berthelot JM, Gouin F, Glemarec J, Maugars Y, Prost A. Possible use of arthrodesis for intractable sacroiliitis in spondylarthropathy: report of two cases. Spine 2001; 26(20): 2297-9.

[33] Kibsgård TJ, Røise O, Sudmann E, Stuge B. Pelvic joint fusions in patients with chronic pelvic girdle pain: a 23-year follow-up. European Spine Journal [Internet]. Sep 23, 2012. Available from: http://www.springerlink.com/index/10.1007/s 00586-012-2512-8 [cited Sep 28, 2012].

[34] Waisbrod H, Krainick JU, Gerbershagen HU. Sacroiliac joint arthrodesis for chronic lower back pain. Arch Orthop Trauma Surg 1987; 106(4): 238-40.

(C) Leonard Rudolf; Licensee Bentham Open

This is an open access article licensed under the terms of the Creative Commons Attribution Non-Commercial License (http://creativecommons.org/licenses/by-nc/3.0/) which permits unrestricted, non-commercial use, distribution and reproduction in any medium, provided the work is properly cited. 